
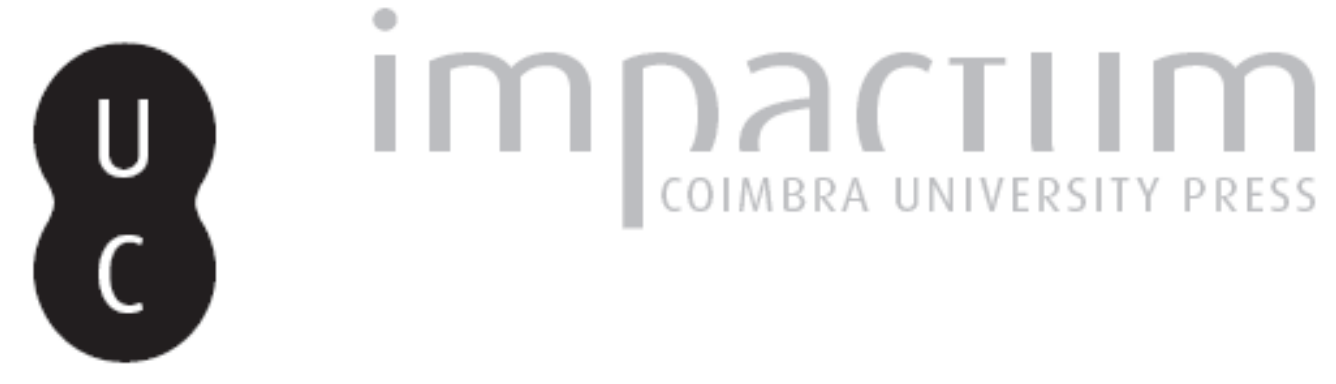

\title{
Expert committees, welfare and education: the transformation of the hospital pharmacist in Great Britain 1920 to 1995
}

\author{
Autor(es): $\quad$ Anderson, Stuart
}

Publicado por: Imprensa da Universidade de Coimbra

URL persistente:

URI:http://hdl.handle.net/10316.2/36779

DOI:

DOI:http://dx.doi.org/10.14195/1647-8622_12_16

Accessed : $\quad$ 26-Apr-2023 11:56:59

A navegação consulta e descarregamento dos títulos inseridos nas Bibliotecas Digitais UC Digitalis, UC Pombalina e UC Impactum, pressupõem a aceitação plena e sem reservas dos Termos e Condições de Uso destas Bibliotecas Digitais, disponíveis em https://digitalis.uc.pt/pt-pt/termos.

Conforme exposto nos referidos Termos e Condições de Uso, o descarregamento de títulos de acesso restrito requer uma licença válida de autorização devendo o utilizador aceder ao(s) documento(s) a partir de um endereço de IP da instituição detentora da supramencionada licença.

Ao utilizador é apenas permitido o descarregamento para uso pessoal, pelo que o emprego do(s) título(s) descarregado(s) para outro fim, designadamente comercial, carece de autorização do respetivo autor ou editor da obra.

Na medida em que todas as obras da UC Digitalis se encontram protegidas pelo Código do Direito de Autor e Direitos Conexos e demais legislação aplicável, toda a cópia, parcial ou total, deste documento, nos casos em que é legalmente admitida, deverá conter ou fazer-se acompanhar por este aviso.

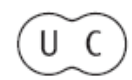


histórias da saúde

ESTUD OSD O SÉCULO

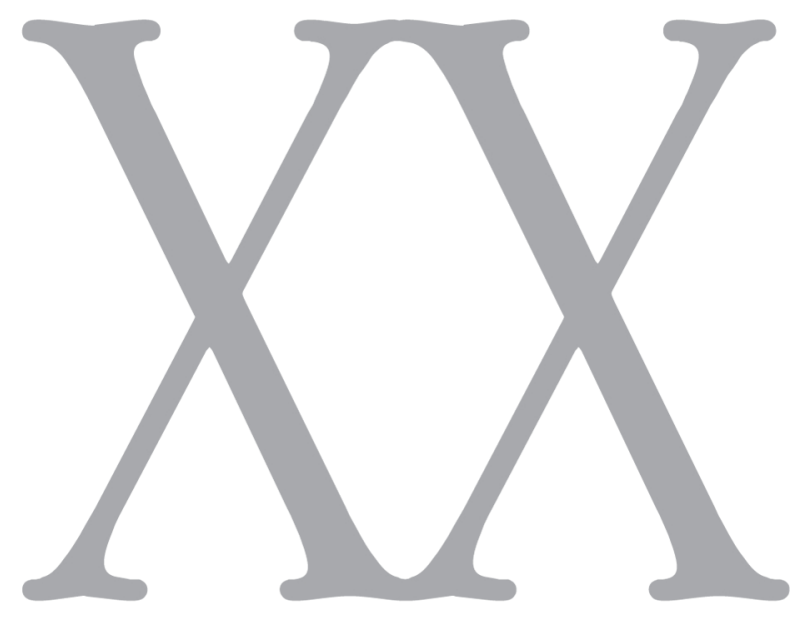

número 12 • 2012

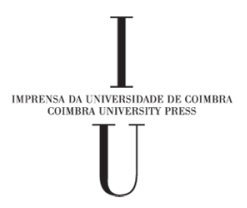




\section{Expert Committees, Welfare and Education}

The transformation of the hospital pharmacist in Great Britain 1920 to 1995

Stuart Anderson 
Stuart Anderson, Doutor. Professor na London School of Hygiene and Tropical Medicine, Londres, Grã Bretanha. E-mail: Stuart.Anderson@lshtm.ac.uk 


\section{Introduction}

The history of hospitals in Great Britain has received considerable attention from historians. Many have placed hospitals in their social and economic context; ${ }^{12}$ whilst others have described the evolution of the hospital from ancient times. ${ }^{3}{ }^{4} \mathrm{~A}$ few have investigated the emergence of hospitals in specific regions of the country, ${ }^{5}$ and there have been many accounts of the history of individual hospitals. ${ }^{7}$ Some of these accounts have explored the development of health professions in the hospital setting, including the growth of medical and scientific specialisations ${ }^{9}$ and the rise of professional control in hospitals. ${ }^{10}$ But a review of these sources identifies few references to the evolution of the hospital pharmacist, to changing relationships between pharmacists and doctors, or to the history of prescribing and dispensing of medicines in hospitals. Yet the role of the pharmacist in British hospitals underwent a continuing process of evolution and transformation, particularly during the twentieth century. To date little of this history has been researched or documented.

Existing histories of hospital pharmacy generally focus on earlier centuries such as the review by Whittet ${ }^{11}$ or document the histories of individual hospital pharmacies, frequently in long established teaching hospitals ${ }^{12} 131415$ rather than on the developing role of pharmacists themselves. Virtually no mention is made of pharmacy in general histories of the British health service in the twentieth century. ${ }^{16}{ }^{17}$ General accounts of the history of pharmacy rarely provide more than a brief outline of the structure of the hospital pharmaceutical service, and make little attempt to review the nature of pharmacy practice in hospitals. ${ }^{18} 19$ Some brief histories of hospital pharmacy institutions have been published in recent years ${ }^{20}{ }^{21}$ but these have usually been commemorative in nature.

In the 1920s hospital pharmacists in Britain were few in number and low in status. Yet by the 1990s there were several thousand of them and many were treated as equals by doctors. This paper explores how this transformation came about using personal testimony and documentary evidence, and identifies key factors that contributed to it. A number of key themes emerge; the introduction of a nationalised health service, the role of expert committees, and changes in education and training. These were themselves shaped by wider social, political and economic factors, such as advances in drug discovery, and increasing occupational specialisation by both doctors and pharmacists.

A number of timeframes can be identified within which key developments in hospital pharmacy occurred. During an initial period of emergence, between 1923 and 1948, hospital pharmacists began to establish a distinct identity, both within the wider pharmacy profession and within the management structures of hospitals. A period of standardisation began with the introduction of the National Health Service in 1948, continuing until publication of the report of an enquiry into the hospital pharmaceutical service in 1970. A third phase of expansion began with the implementation of the recommendations of this report, and continued until 1982, 
during which time the service underwent its greatest period of development. A fourth phase began in 1982, when changes in the financial climate in the NHS, including pressure to make efficiency savings, and subsequent difficulties in recruiting pharmacists, brought the period of expansion to an end. The period from 1982 to 1991 was one of consolidation, during which the gains of the 1970s and early 1980s were built upon and developed. But we begin by considering the state of hospital pharmacy in Great Britain before 1923.

\section{Hospital pharmacy in Great Britain before 1923}

Pharmacy in hospitals, concerned with the making and supplying of medicines, traces its origins to antiquity. The first hospitals in Great Britain where pharmacy was practiced were the Roman military hospitals, or valetudinensis. ${ }^{22}$ The traditions of pharmacy were continued through medieval hospitals and monastic infirmaries, where monks grew herbs and prepared medicines from them. The eighteenth century saw the founding of many new hospitals, often the result of patronage by local benefactors. The early nineteenth century saw a new trend with the founding of small specialist hospitals, usually be doctors themselves. ${ }^{23}$ These developments were accompanied by a steady growth in the number of apothecaries employed in hospitals. In the eighteenth and nineteenth centuries the hospital apothecary usually combined the roles of dispenser of medicines and resident medical officer. Other duties were often added as new discoveries were made; at Westminster Hospital in London the apothecary also acted as anaesthetist, and at St George's Hospital he also acted as medical electrician. ${ }^{24}$

By the middle of the nineteenth century the days of the apothecary as the person responsible for dispensing medicines in hospitals were on the decline. ${ }^{25}$ The Pharmaceutical Society of Great Britain, founded in 1841 and bringing together chemists and druggists with those apothecaries who opted to practice as pharmacists rather than as general medical practitioners following the Apothecaries Act of 1815, introduced formal training and awarded qualifications. From about 1850 voluntary hospitals began replacing retiring apothecaries with qualified pharmacists, although most public institutions (municipal infirmaries, asylums and sanitoria) chose not to employ pharmacists, as there was no legal requirements to do so, relying largely on unqualified dispensers. ${ }^{26}$

Continuing practices established by their predecessors, hospital pharmacists in the late nineteenth century frequently took on additional occupations. They were, for example, amongst the first to provide radiography services following the discovery of X-rays in $1895,{ }^{27}$ although such involvement was short-lived as the technology advanced rapidly and the need for trained radiographers became apparent. In the last years of the century hospital pharmacists began to organise themselves. In 1897 a Poor Law Dispensers Association was formed, followed in 1898 by a Public Dispensers Association, aimed at asylum, prison and charity dispensers and a few hospital ones. Its principal objectives were 'to protect and further the interests of public dispensers' and 'to secure adequate remuneration for dispensers, and generally to raise their status. ${ }^{28}$ 
In 1900 the two Associations amalgamated to form the Public and Poor Law Dispensers Association. For the first time pharmacists working across a range of public institutions, but not the voluntary hospitals, were represented by a single organisation. The challenges were great. Frederick Bullen later recalled that at the time the Association was founded:

The dispenser was of no known origin, being perhaps an intemperate un-certificated medico, an ex-naval or army compounder, an Apothecaries Society diplomat, or less often, a chemist and druggist. ${ }^{29}$

The Assistants Certificate of the Society of Apothecaries, established in 1820, was aimed at those wishing to work in the pharmacies of public institutions. ${ }^{30}$ In the early part of the twentieth century, hospital pharmacy was the poor relation of retail pharmacy. The numbers employed were small, the pay was low, and the service relied heavily on the dedication of women. Working conditions were usually poor, with pharmacies themselves often located in hospital basements.

Emergence: Early developments 1923 to 1948

Hospital pharmacy, then, was not seen as an attractive career option by young pharmacists starting out in the early 1920s. William Phillipson had begun his career in retail pharmacy in Manchester, but he disliked counter work, and was persuaded to try hospital pharmacy instead. He recalls that:

At that time it was considered a 'dead-end' profession, in evil repute, and certainly un-remunerative. It was even said that only men who wanted time to drink and lacked ambition became hospital 'dispensers', but there were unlimited prospects for progress. The medical profession had not at that time taken over the ancillary departments, and as a pharmacist you were more closely involved in their day to day working. ${ }^{31}$

In 1923 pharmacists in public institutions came together with those in the voluntary hospitals to form the Guild of Public Pharmacists. Pharmacists from the full range of institutions began to forge a common identity. With this came greater knowledge about what their colleagues did, and recognition of specialist expertise developed. Articles about practice in particular types of institution began to appear in the Guild's publication Public Pharmacist. Pharmacists who worked in the less glamorous areas of practice, such as in mental hospitals and sanatoria, began to be accepted by other hospital pharmacists. But hospital pharmacy remained an unattractive option to young pharmacists. John Lloyd began working as a hospital pharmacist in the early 1920 s in Manchester. He recalls that:

Prior to the formation of the Guild few pharmacists deliberately chose the hospital service as a career. Apart from a few dedicated men it was largely the refuge of those who for one reason or another failed to make the grade in retail pharmacy, and they had few professional aspirations. ${ }^{32}$ 
The increasing availability of more effective medicines from the 1920 s led to the need for a degree of specialisation in hospital pharmacy; the use of barbiturates in the 1930s, for example, led to the development of specialist expertise amongst pharmacists in psychiatric hospitals. The greater use of drugs such as digoxin for heart conditions and insulin for diabetes led to a growing awareness amongst hospital pharmacists of the need for accurate doses. Yet their training by apprenticeship methods failed to prepare them for such roles. In the late 1920s hospital pharmacy was being practiced very much as it had been for years. Frank Newman recalls that

When I was first appointed [in 1921] to University College Hospital there were on the shelves bottles with gilt and black labels on them; bottles which I am sure had been on the shelves for over 50 years. The fact is that when I first went into pharmacy the things used had been used for 50 or more years and were in fact used for many years after. ${ }^{33}$

By the 1930s there was a growing recognition that changes were required if pharmacists were to deliver the kind of services that were increasingly needed in hospitals. On the eve of the Second World War, in 1939, the Pharmaceutical Society of Great Britain carried out a survey of hospital pharmacy. ${ }^{34}$ It revealed that considerable progress had been made in recent years; two-thirds of the 397 hospitals with more than 100 beds employed a full-time pharmacist, and $50 \%$ of those with less than 100 beds used outside pharmacists to supervise dispensing. But enormous problems remained; whilst emphasising the need to recruit the best-qualified and most enterprising pharmacists into the service, the report provided no answer to the fact that the income offered was lower than it was for both independent proprietors and managers of company chemists.

For pharmacists considering a career in the hospital service in the 1930s it was still prudent to have additional qualifications. Many of the jobs advertised were single-handed and involved carrying out additional duties. Lance Summerfield recalls applying for a post advertised as pharmacist-biochemist:

The job that I applied for [at the Norfolk and Norwich hospital] was advertised in the Pharmaceutical Journal, and was for a 'pharmacist-biochemist'. Many of the jobs for pharmacists in the smaller hospitals were advertised in that way, and you would have to have some sort of qualification in biochemistry as well. ${ }^{35}$

Training in biochemistry was encouraged by the Pharmaceutical Society of Great Britain, which awarded its own Diploma in Biochemical Analysis. John Myers, who later became a member of the Pharmaceutical Society's Council, recalls the discussions which took place before the Society introduced its Diploma.

The reason that this course was started was that in those days they didn't have a full-time job for the hospital pharmacist. He did this in his spare time, the examination of body fluids. The Pharmaceutical Society of Great Britain set the exam and marked it, but it was taught at Schools of Pharmacy. ${ }^{36}$ 
The reliance on the apprenticeship system meant that the focus of training for pharmacists was practical skills (making pills and using ointment slabs) rather than on knowledge about the actions and uses of drugs. Although apprentices went to college one day a week the emphasis was on the extraction, synthesis and identification of drugs rather than on their actions and uses. Indeed this was often spelled out explicitly to students. Jack Bearman recalls:

I had learnt virtually nothing about the actions and uses of drugs during the apprenticeship. So when I got to [Chelsea] college [in 1937] I asked one of the lecturers when we would be taught about it. His answer was 'you don't need to know anything about that. ${ }^{37}$

At this time the professional body was more interested in extending the nonpharmaceutical aspects of the pharmacist's role rather than the pharmaceutical ones. There was a suggestion that pharmacists should take on a much wider role in relation to hospital supplies; the 1939 survey carried out by the Pharmaceutical Society recommended that 'the role of the pharmacist as hospital supplies officer needs greater stress. ${ }^{38}$ This was to meet with strong opposition with introduction of the National Health Service in 1948.

The tradition of the hospital pharmacist combining the dispensing of medicines with other duties continued well into the twentieth century. In some places pharmacists even continued to carry out the duties of pathologist. Eric Tallett undertook his apprenticeship at a hospital in Burnley, Lancashire. The pharmacist there had received his own training at the beginning of the century; it had included the performing of post-mortem (PM) examinations, and he continued to carry these out into the 1940 s. Eric Tallett recalls:

He personally carried out the PMs. He was under the supervision of the pathologist at the Royal Infirmary, who came over about once a fortnight... There was no medically qualified person present at the PM. The mortuary was next to the pharmacy, with a connecting door. On more than one occasion he would walk into the pharmacy with blood dripping off his gloves, and say 'give me some cotton wool'. And he would leave a trail of blood, some of which dropped into the pharmacy baskets! He did at least one per week, sometimes two or three. He spent very little time in the pharmacy. ${ }^{39}$

Such activities were the exception rather that the rule, and by this stage dual occupations were increasingly rare. Pharmacy was beginning to be transformed by the appearance of ever-more effective medicines, such as the sulphonamides in the late 1930s and penicillin in the 1940s. The supply of penicillin became a source of friction between hospital pharmacists and pathologists. Pathologists were responsible for infection in the hospital, and penicillin was used to treat infection. At most hospitals the limited supplies available were sent to the pathology laboratory, which would then have the task of preparing the injections. When supplies improved many pathologists considered that penicillin should only be issued by them. Geoff Mander recalls: 
After the war, penicillin became available to hospitals. The first scarce supplies had been reserved for military casualties. An eminent pathologist suggested that, as it had been discovered by a pathologist, and that only they had the necessary techniques and skills in aseptic [sterile] handling, they should control and issue it. ${ }^{40}$

There were however practical reasons why pathology should handle the penicillin. Because it was in short supply the signature of the pathologist was usually required. Arthur Shaw recalls:

Because supplies were so short, penicillin couldn't be used unless bacteriology agreed that it was appropriate to use it. So you had to have the initials of the head of the path lab, who was a doctor, on it. And that meant that the penicillin was being kept in the path lab to send out to the wards. There were people in the path lab making solutions for injection, and other things. ${ }^{41}$

This often resulted in requests for advice from the pharmacy department, and before long pharmacists were being asked whether they could prepare the injections. In most hospitals pathologists were only too happy to hand over responsibility for this task. Geoff Mander recalls that 'after a while, the volume of work, and the complex logistics of distribution defeated them, and they were pleased to hand over responsibility to pharmacy. ${ }^{32}$

The introduction of new drugs created other openings for hospital pharmacists. Eileen Hirst recalls that antibiotics presented an opportunity for pharmacists to start visiting wards.

We did start a little bit of a ward delivery service, mainly because of the antibiotics. It wasn't a good idea to put penicillin injections in the basket where they would be sitting around all day, because they had to be in the fridge. So we delivered those direct to the ward and made sure they went in the fridge; which was really the beginning of the ward pharmacy service, because it was the first time we were able to go onto the ward and say 'I've just brought these, I'll put them in the fridge for you' and that was how it all started. ${ }^{43}$

The Second World War halted any prospect of further progress, although it did increase the opportunities for women to make a career in hospital pharmacy, and shortages of key items led to pharmacists developing improvisation skills. But even with new drugs appearing little changed in relation to the pharmacist's education. Basil Trasler recalls:

We learnt very little about what drugs were for during the apprenticeship [1946-49]. This was not rectified at college. This attitude to not needing to know anything about how they worked, the attitude that we were not expected to know, persisted for years. ${ }^{44}$

Except in the large hospitals most hospital pharmacists effectively worked as sole practitioners. Most items requested were either made up individually or issued 
from stock bottles often supplied by wholesalers. Some items might be sent from the pharmacy of a larger hospital to that of a smaller one, but cooperation between hospitals was usually very limited. The need for better coordination became clear with introduction of a national health service in 1948.

Standardisation: The impact of welfare 1948 to 1970

Initial steps towards a national health service had been taken with passage of the National Health Insurance Act in 1911, which covered working men, but its main impact was on pharmacy in the community rather than in hospitals. ${ }^{45} \mathrm{With}$ implementation of the National Health Service (NHS) Act in 1948, coverage was extended to the whole population and municipal and voluntary hospitals were brought together. For hospital pharmacists nationalisation led to greater standardisation of services, and unofficial arrangements (such as pharmacists undertaking post mortems) ended. But it also led to disputes over occupational boundaries; for hospital pharmacists a serious threat came from a new group of staff appointed in the new NHS, supplies officers.

Keith Gisborne was appointed as chief pharmacist at a municipal hospital just before the NHS was introduced. He remembers that

I had to go to the hospital secretary. He signed the orders personally for all the drugs I wanted, from wholesalers and manufacturers such as Evans Medical and BDH. He often queried the prices of things; he wanted to know what was going on, because he and the finance officer between them held the purse strings. I would be taking orders to him two or three times a week. I don't remember any pressure to cut down on the amount of drugs being supplied. He had faith in what I was doing, that I wasn't being reckless.

He detected a change in attitude following introduction of the NHS on 5 July 1948.

It became a free for all...there wasn't the restriction after July the fifth. They didn't query so much what was going on, they took it for granted. The arrangement whereby the hospital secretary signed the orders continued, but once we got a supplies officer, he took that over. He was one of the first appointments made, within about six months of the NHS. But I'm still having to take orders to him. This is what annoyed me so much. It was a cause of great discontent between the Pharmaceutical Society and the hospital service, that the supplies officer had to sign the orders, and it took several years of negotiation before that was rescinded. ${ }^{46}$

Many hospital pharmacists drew attention to the lack of qualification of the supplies officer to purchase pharmaceuticals, by sending them requisitions for inappropriate quantities of expensive drugs, or for non-existent preparations. The issue was taken up by the Guild of Public Pharmacists, and in 1952 it succeeded in convincing the Ministry of Health that the acquisition of pharmaceutical supplies should be the responsibility of pharmacists rather than supplies officers. ${ }^{47}$ 
The pharmacy service in hospitals at the start of the NHS was still a basic one, in which wards ordered what they wanted and sent orders to the pharmacy on a daily basis in baskets. Bill Brookes recalls the service when he started in the late 1940s:

There were baskets coming down. From all the wards, all at the same time. They were open wicker baskets. There were large numbers of them. You had a job to find your way around; the floor was filled with them. Nothing was pre-packed, you had to refill everything. Just straightforward requisitioning, a page of a book or a sheet of paper from the nursing staff. And you supplied what they'd asked for. You also had boxes, locked boxes coming in from outside hospitals, two or three times a week. And again, these were all requisitions, because two of them were General Practitioner hospitals, and what they asked for they got. ${ }^{48}$

With implementation of the NHS pharmacists at different hospitals began to work together. One of the first areas for co-operation was purchasing, with a view to obtaining bulk purchase discounts. The first group contract for pharmaceuticals was established in 1948 in the Yorkshire area. For many hospital pharmacists these annual meetings were the first real opportunity to meet with their colleagues and to discuss issues of common interest. But as many of them worked single-handed they could only get away if cover was provided, often by a pharmacist from the district hospital.

Early steps were taken to improve the pay and conditions of service of hospital pharmacists. The Pharmaceutical Whitley Council, which negotiated terms at the national level between a staff and management side, had been the first to be established following introduction of the NHS. ${ }^{49}$ A new grade of 'senior pharmacist' was agreed, recognising the need for experienced support. But division of labour within pharmacy departments remained very limited; chief pharmacists were still heavily involved in day to day duties, and all staff including the chief did whatever needed to be done.

Implementation of the NHS also provided the impetus required for a further review of the service. A Sub-committee of the Standing Pharmaceutical Advisory Committee was appointed on 2 November 1951 under the Chairmanship of Sir Hugh Linstead to 'review the arrangements for the provision of pharmaceutical services in hospitals, and to advise on the most efficient and economical organisation of those services. ${ }^{50}$ It was to be another four years before the Linstead Committee published its report. ${ }^{51} \mathrm{It}$ identified ten activities as the main responsibility of pharmacy departments, including advising prescribers and training pharmacy students. It found that many pharmacy departments were too small to undertake all the functions, and recommended that hospital pharmacies work together in groups. ${ }^{52}$ It also recommended that some activities should cease, including biochemical analysis and the supply of surgical instruments and X-ray materials. But the health circular which accompanied the report was advisory rather than mandatory, and as a result the recommendations were largely ignored, except in two or three areas. 
Further development of the service was hampered by the failure to implement the recommendations of the Linstead Report. Before the NHS there was little specialisation by function in hospital pharmacies. Even the largest hospitals had no more than a dozen staff in the pharmacy. Some did have large manufacturing facilities, with tablet machines, stills and large autoclaves for injectables; and some pharmacists began to develop considerable expertise in manufacturing, although for newly qualified pharmacists and apprentices the normal practice was to rotate around the various sections of the pharmacy, such as the inpatient and outpatient dispensaries.

A further review of the service was carried out in 1957, and a second Linstead Report published in 1958. ${ }^{53}$ This time the recommendations were accompanied by a mandatory directive, so they were largely implemented, despite many obstacles being placed in the way. The main recommendation was again that hospitals should work together as groups to achieve economies of scale. Opposition to it was substantial: strong voices were raised by teaching hospital pharmacists, many of whom could see little to be gained by even larger units; and chief pharmacists in small hospitals saw it as a major threat to their independence. Although many pharmacists took on the title of group chief pharmacist during the 1960s, many had little to do with the smaller hospitals which were nominally part of their groups. Full implementation had to wait for yet another enquiry in 1970 .

Following reports of high levels of drug administration errors in the early 1960s, a number of teaching hospitals introduced initiatives aimed at dealing with the problem. Amongst these was the sending of pharmacists onto wards and departments not only to check medicine stocks but also to check prescriptions charts and administration records. Chris Barrett introduced the service at the London Hospital.

The function of the ward pharmacist was to monitor prescription sheets to make sure that the prescription itself was safe and appropriate, and was written in such a form on the structured prescription sheet that the nurse could understand how to administer that drug...you were legitimising the administering from stock process. ${ }^{54}$

Ward pharmacy was very demanding on pharmacists' time, and changes in the way medicines were supplied to the wards were introduced at the same time. Chris Barrett continues:

An individual item as opposed to a stock item would be dispensed, but without directions. It was called temporary stock. The reason for that was to release as much time as you could for that first action of looking at the appropriateness of the prescription...To get ward pharmacy going...you've got to divert a lot of pharmacist time.. If you don't go to town on working out how you develop that time, the whole thing falls to bits. ${ }^{55}$

The changing role of the hospital pharmacist also placed increasing demands on the pharmacist's knowledge and skills. The profession moved from apprenticeship to 
graduate entry in 1967, and the practical skills of the pharmacist (the ability to make pills and mixtures) were now less important than the pharmacist's knowledge about the actions and uses of drugs. Yet schools of pharmacy were slow to respond to the changing role of the pharmacist, maintaining an emphasis on pharmaceutical sciences and dispensing practice.

During the 1950s and 1960s a large number of new drugs were marketed, a period which became known as the therapeutic revolution. ${ }^{56}$ As a result increasing numbers of drug company representatives visited hospitals to see doctors and pharmacists, leaving detailed literature about their products. It became more difficult for the chief pharmacist to be on top of day to day matters, as well as undertaking more managerial functions. As a result, the Guild of Public Pharmacists campaigned for a new grade of hospital pharmacist, the 'deputy chief pharmacist'. The new grade was agreed by the Pharmaceutical Whitley Council, and the first appointments were made in 1956.

At first, there was resentment and opposition to such posts, but such criticism was generally short-lived, and the new breed of deputy chief pharmacists quickly established themselves as vital members of the hospital pharmacy team, usually taking responsibility for the day to day running of the pharmacy department, and frequently spearheading innovation. Between 1956 and 1970 most hospitals of any size appointed a deputy chief pharmacist, although often from amongst its current establishment, so there was often no overall gain in staff numbers.

There was however often a reluctance to change amongst the older breed of chief pharmacist. Joan Greenleaf took up the post of chief pharmacist at St James Hospital in Leeds in 1969. She describes the situation she inherited from her predecessor.

It was old-fashioned in one sense, but again the status of pharmacy was extremely high, because Hugh Linstead had been chairman of the management committee, and so they thought pharmacy was something to be reckoned with. And they'd had a new pharmacy during Linstead's time. And they'd also had a very good, though old-fashioned by current standards, chief pharmacist who had run the place meticulously, although he hadn't moved into the new era. So it was quite an interesting challenge to be able to move forward and bring in a lot of modern practices, but I must say that it was a very good department to inherit. ${ }^{57}$

The post-1948 period also saw the growth in the employment of unqualified staff working in hospital pharmacies. Although not pharmacists, many had dispensing qualifications and were placed in charge of the pharmacies where they worked. Hospital pharmacies also began to employ other groups of staff, such as porters and pharmacy assistants, who were usually women without qualifications who undertook duties such as packing, labelling and bottle washing. As pharmacy departments in larger hospitals grew, so labour became more divided, with the appointment of storekeepers, secretaries and receptionists. 
Despite the two Linstead reports the fundamental problems of the hospital pharmaceutical service (inability to recruit, lack of career progression, poor pay and fragmentation of the service) remained largely unresolved throughout the $1950 \mathrm{~s}$ and 1960s. ${ }^{58}$ Nevertheless some progress was possible in implementing some of the recommendations. Ward pharmacy received official recognition in the 'Report on the Control of Dangerous Drugs and Poisons in Hospitals (the Aitken Report). ${ }^{59}$ Through this the Department of Health finally decreed that all NHS hospital pharmacies must be in the charge of a registered pharmacist.

But despite such successes major problems persisted and it was clear that a major enquiry into the service was required. Constant lobbying of the Minister of Health eventually led to the appointment of a Working Party on the Hospital Pharmaceutical Service in April 1968. It was chaired by a political economist, Sir Noel Hall, and only four of its eleven members were pharmacists. It collected a great deal of evidence, and its report (the Noel Hall Report) was eventually published in 1970. It made a total of sixteen recommendations, covering organisation, staffing, career structure and training (pay was outside its remit). The principal recommendation was that:

Hospital pharmaceutical services should be organised on a scale large enough to ensure that pharmacists are fully occupied on duties requiring their professional and managerial ability; to provide scope for the optimum use of technicians and other supporting staff; and to create the conditions needed for a satisfactory career structure. The early appointment of a Regional Pharmacist is highly desirable to assist Regional Hospital Boards to undertake the responsibilities envisaged. ${ }^{60}$

This time the recommendations of an expert committee were implemented more or less in full. Unlike the Linstead Committee it had an independent chairman, pharmacists were in a minority, and it reported directly to ministers rather than to a higher level committee. Noel Hall areas were created within the boundaries of new regional health authorities created in 1974 following passage of the National Health Service Reorganisation Act of 1973. Large groups of hospital pharmacies were managed as single entities for the first time; the maintenance of large administrative units has remained a feature of hospital pharmacy in Great Britain ever since.

The threat from supplies officers was to re-emerge again in the 1980s, this time following a report commissioned by the Department of Health. The MMM report on drug procurement ${ }^{61}$ recommended the establishment of regional centres for drug purchasing, and a new structure for the supplies service which would give them overall responsibility for the purchase of pharmaceuticals. Once again this initiative was confronted both locally and nationally, with a take-over by supplies officers eventually being averted.

A further dispute over occupational boundaries came from clinical pharmacologists. Clinical pharmacology gained considerable momentum following the 
thalidomide tragedy of 1961 . By 1965 it was being suggested that there should be a clinical pharmacology department in every hospital. Two reports published in 1965 drew attention to the high level of errors resulting from the transcription of medication sheets. ${ }^{62}$ They highlighted an important role for hospital pharmacists; at both the London and Aberdeen hospitals it was the pharmacist who was seen as the person who should be checking the prescription for errors, interactions and incompatibilities.

Hospital pharmacists also became more involved in initiatives designed to control the costs of drugs. Connie Ashcroft, working at Manchester Royal Infirmary in the 1960s, remembers how concern with the high cost of drugs led to the formation of drugs and therapeutics committees.

\begin{abstract}
We reached the heights of fame for being the most expensive teaching hospital [in the country]. They decided that they would have to do something about it, and Lloyd (the chief pharmacist) came up with this idea that any new drug that was going to be bought in had to be signed for by the consultant, who said how many patients he was going to try it on, and why he wanted it. Eventually these pink forms went to the Drug and Therapeutic Committee, which they set up. If the Drug and Therapeutic Committee agreed, or at least its chairman did, he would go and see his colleagues and tell them [whether] they could have it or not. ${ }^{63}$
\end{abstract}

Implementation of the Noel Hall recommendations led to a range of developments including the emergence of specialisation. Many of the most experienced chief pharmacists were taken out of the hospital setting and appointed as regional or area (and later district) pharmaceutical officers. Most regions established posts in quality control and drug information, the first being advertised in 1973. Because of both the shortage of pharmacists generally in the hospital service, and specifically the lack of expertise in these areas, many of those recruited came from the pharmaceutical industry. They brought with them a new approach and fresh ideas to hospital pharmacy. Substantial numbers entered the hospital service, encouraged by the relatively generous salaries then on offer, and the prospect of rapid promotion to even higher and more generously paid grades. Between 1968 and 1982 the number of pharmacists employed within the NHS hospital pharmaceutical service more than doubled, from under 2,000 in 1968 to over 4,000 in $1982 .^{64}$

Ward pharmacy evolved into clinical pharmacy, aimed at optimising the drug therapy of individual patients. This growth led to the need for more highly trained individuals who could not only practice at a high level but could also act as role models for other pharmacists. The chosen solution was the creation of an MSc in clinical pharmacy, the first of which was established at the School of Pharmacy, University of London in 1980. Initially small numbers of such pharmacists were trained, and many returned to their base hospitals and established local in-house training programmes for pharmacy staff. 
The late 1970s and the early 1980s were periods of expansion in hospital pharmacy, with substantial growth in specialties such as drug information, manufacturing and quality control. There was also sub-division of specialist posts, often on a regional basis. In the field of manufacturing specialist posts emerged for sterile and non-sterile manufacturing, and pre-packing. Specialist posts also emerged for the preparation of intravenous additives and solutions for parenteral nutrition, for the preparation of radioactive medicines for diagnostics purposes, and in core distribution and supply functions. Others emerged in formulary development, computer applications and purchasing.

By the 1980s salaries in hospital pharmacy had again begun to lag behind those in community pharmacy, prospects for rapid promotion were becoming fewer, and economy measures in the NHS were beginning to affect pharmacy establishments. The result was the first of several cycles of recruitment problems that were to seriously hamper further development of the service during the last decades of the twentieth century. But recruitment problems were not confined to pharmacists; pharmacy technicians also became increasingly difficult to recruit, and various strategies to improve recruitment and retention of such staff were implemented. These included greater delegation of functions and responsibilities to more experienced pharmacy technicians.

\section{Consolidation: The rise of the specialist clinical pharmacist 1982 to 1995}

The service found itself subjected to further review in 1985, more by accident than design. A Committee of Enquiry, asked to consider all branches of pharmacy and pharmacy education, was appointed by the Nuffield Foundation and chaired by Sir Kenneth Clucas. The Nuffield Report, published in 1986, included twenty-one recommendations relating to hospital pharmacy. These supported extending the role of the hospital pharmacist, expanding specialist services, and encouraging full use of support staff. In particular it promoted clinical pharmacy.

Clinical pharmacy should be practised in all hospitals. The initiative should rest locally; but there should be more studies of the real needs and more central coordination. The first aim should be a general statement of the clinical pharmacy service that should be provided in all hospitals. ${ }^{65}$

In due course this more clinical role for the hospital pharmacist received official support from the Department of Health. In 1988 it issued a health circular, 'The Way Forward for Hospital Pharmaceutical Services', ${ }^{66}$ which indicated that clinical pharmacy, emphasising the monitoring of drug therapy and the control of expenditure, should be available in all hospitals. Increasingly pharmacists spent most of their time on the wards, leaving dispensing and other duties to support staff. As pharmacy technicians became more skilled and took greater responsibility for their own work the need for higher grade staff became apparent. ${ }^{67} \mathrm{~A}$ new grade of senior pharmacy technician was formally recognised in 1982, followed in the 1990s by the grade of chief technician. 
By the mid-1980s further expansion of the hospital pharmaceutical service was proving more challenging. Financing the health service was reaching crisis point, and the government commissioned a review of the health service which transformed NHS management. ${ }^{68}$ The Griffiths Report of 1983 introduced general management into the NHS, along with a range of measures aimed at economy and efficiency. For hospital pharmacy managers getting additional established posts during this period became much more difficult. Colin Hetherington was chief pharmacist at a teaching hospital in Leeds at the time.

I think we'd only got one pharmacist post added to the establishment.... We just used the standard arguments, about increasing workload and so forth. I mean we'd just got this sterile fluids unit to look after, so that was another aspect of work that was new. So all these things just indicated that we needed more resources. And I don't think we increased our technician numbers at all. So I mean it was a very minor kind of increase. ${ }^{69}$

Arguments demonstrating the impact that having pharmacists on the wards where they could influence prescribing decisions and suggest ways of saving money were often favourably received. This led to the recruitment of additional young pharmacists and the further expansion of clinical pharmacy services. Increasing numbers obtained higher qualifications in clinical pharmacy, either at the diploma or masters level. There was now greater acceptance of ward-based pharmacists by doctors, and many of them now expected to have a pharmacist as part of their team. Increasingly the demand was for clinical pharmacists who specialised in drug therapy in a specific medical specialty, such as AIDS, cardiology and intensive care. This development led to greater integration with medical colleagues and to the creation of special interest groups, the setting up of specialist conferences, and the creation of new journals.

This trend was given greater momentum with the creation of clinical directorates as part of the NHS changes resulting from implementation of the National Health Service and Community Care Act of 1991. This amounted to another major reorganisation of the NHS, as it aimed to reform both management and patient care by introducing an internal market, changes which had been announced in the White Paper Working for Patients. ${ }^{70}$ This created hospital trusts, which had much greater financial and political autonomy than other NHS hospitals. For hospital pharmacists the move meant than some of their staff were now formally employed by the clinical directorates rather than by the pharmacy, whilst many directorates now expected their own pharmacist at the same time as establishments were being cut.

Further drives to ensure appropriate use of pharmacy staff resulted from a review of skill mix in $1992^{71}$ but attempts to implement further changes were overtaken by changes resulting from the NHS and Community Care Act. In future the dominant force shaping hospital pharmacy in the NHS was to be market forces. For hospital pharmacy the period of rapid expansion and development was over. In the years that followed it came under the same pressures of increasing workload and diminishing resources that were faced by all staff groups in the NHS. Recruitment difficulties which marred the continuing 
development of the service in the 1990s were further exacerbated by the move to a four year degree programme for pharmacy introduced in 1997. Hospital pharmacists today work closely with clinical colleagues, but continuing financial pressures, and ongoing difficulties in recruiting pharmacists, means that they entered the twenty-first century with little more optimism that they entered the twentieth.

\section{Conclusion}

The hospital pharmaceutical service in Great Britain underwent a dramatic transformation during the course of the twentieth century. This paper has described the main changes and explored some of the factors that have contributed to them. Three key factors emerge from this analysis; the role of expert committees of enquiry; the introduction of a national health service; and changes in the pharmacist's education.

Change in the pharmacist's education was a pre-requisite for development of the service. The apprentice system, in which apprenticeship learnt mainly from masters who had themselves been taught twenty or thirty years previously by the same method, proved totally inadequate as a means of preparing pharmacists to practice in a world where new drugs were being introduced on almost a weekly basis, even when that training was supplemented by attendance at college. Although the first pharmacy degrees were awarded in 1904, most pharmacists continued to be trained through apprenticeship until the 1960s. The move to degree only entry to pharmacy in 1967 was therefore crucial to the future development of pharmacy in hospitals.

The shift away from more practical skills such as making pills to an emphasis on the actions and uses of drugs was essential not only to meet the needs of these changing roles, but to raise the status of the pharmacist particularly in the eyes of doctors. From a subservient role in the 1920s the hospital pharmacist rose in stature to being seen as an equal by many doctors in the 1990s. This was largely the result of changes in pharmacists' education. Their status and social standing was further enhanced when many studied for higher qualifications including doctoral degrees.

The role of expert committees of enquiry has been a crucial feature in the development of the hospital pharmaceutical service in Great Britain during the twentieth century. The service has been subject to no less than five such surveys: the committee of enquiry set up by the Pharmaceutical Society in 1939; the two Linstead reports, in 1955 and 1958 respectively; the Noel Hall Report in 1970; and the enquiry appointed by the Nuffield Foundation in 1986. The reasons why Noel Hall succeeded where Linstead failed have been explored in more detail elsewhere. ${ }^{72}$ But even the less successful expert committees played an important part in drawing attention to aspects of the service that were in need of urgent attention, and all contributed to shaping the course of future enquiries.

But perhaps what has played the greatest part in shaping hospital pharmacy in the twentieth century has been the introduction of a national health service. Before 1948 hospital care in Great Britain was provided by an assortment of voluntary, municipal 
and independent providers. The practice of hospital pharmacy reflected that diversity, and suffered from a lack of coherence, uniformity and vision. Nationalisation of the hospitals provided the impetus for change, and helped pharmacists to appreciate both what was needed and what was possible.

These features were however facilitated by other developments occurring at this time. Key amongst these were technological developments, particularly the emergence of larger numbers of effective drugs, together with new methods and techniques for diagnosing and treating disease. Increasingly pharmaceutical manufacturers produced medicines in ready to use form, often as tablets and capsules, so that the need for pharmacists to make up medicines individually diminished greatly, although hospitals often used items that were not commercially available.

In many ways hospital pharmacists had to re-invent themselves in the second half of the twentieth century. Indeed had they not done so it is difficult to see how they could have survived as a separate professional group. But the process was not always an easy one. They had to deal with a range of challenges from other professional groups, and repeatedly had to negotiate on occupational boundaries.

Hospital pharmacists were, however, very successful in taking advantage of the opportunities presented, and this success has often been the envy of other professional groups. The increasing size and scope of the hospital pharmaceutical service provided the opportunity for greater specialisation amongst pharmacists and their support staff. The growth of specialisation, particularly in the post-Noel Hall period, allowed pharmacists to create new areas of activity and develop greater involvement with medical and nursing staff. Co-operation between hospitals within localities, and the greater size that resulted, allowed greater division of labour to become possible. Tasks requiring lesser expertise were delegated to less qualified staff. This division of labour helped to create a more professional identity for hospital pharmacists and to reinforce its boundaries.

The twentieth century thus witnessed a dramatic transformation of the hospital pharmacist in Great Britain. Many factors contributed to this transformation, but hospital pharmacists themselves were very successful in grasping the opportunities presented. Together, the changes described in this paper represent the rapid professionalisation of the hospital pharmacist in Great Britain during this period. 


\section{References}

1 ABEL-SMITH, B. - The Hospitals 1880-1948: A Study in Social Administration in England and Wales. London: Heinemann, 1964.

2 GRANSHAW, L. - “The Hospital”. In BYNUM, W.F.; PORTER, R. (eds.) - Companion Encyclopaedia of the History of Medicine. London: Routledge, 1993. Volume 2.

3 DAINTON, C. - The Story of England's Hospitals. London: Museum Press, 1961.

${ }^{4}$ POYNTER, F. N. L. (ed.) - The Evolution of Hospitals in Britain. London: Pitman Medical Publishing, 1964.

5 PICKSTONE, J. V. - Medicine and Industrial Society: a History of Hospital Development in Manchester and its Region 1752-1946. Manchester: Manchester University Press, 1985.

${ }^{6}$ RISSE, G. B. - Hospital Life in Enlightened Scotland: Care and Teaching at the Royal Infirmary of Edinburgh. Cambridge: Cambridge University Press, 1986.

7 CLARK-KENNEDY, A. E. - The London: A Study in the Voluntary Hospital System. London: Pitman Medical Publishing, 1963. Volume 2: The Second Hundred Years 1840-1948.

${ }^{8}$ MEDVEI, V. C.; THORNTON, J. L. - The Royal Hospital of Saint Bartholomew 1123-1973. London: St Bartholomew's Hospital, 1974.

9 MERRINGTON, W. R. - University College Hospital and its Medical School: A History. London: Heinemann, 1976.

${ }^{10}$ GRANSHAW, L.; PORTER, R. (eds.) - “The Hospital in History”. London: Routledge, 1989.

11 WHITTET, T. D. - "The History of Pharmacy in British Hospitals". In POYNTER, F. N. L. (ed.) - The Evolution of Pharmacy in Britain. London: Pitman Medical Publishing, 1965. p. 17-44.

12 DOPSON, L. - "A History of Pharmacy at Bristol Royal Infirmary." Chemist and Druggist. 165 (1956) p. 622.

13 GRAINGER, H. S. - "The Apothecaries of the Westminster Hospital." Public Pharmacist. 19 (1962) p. 102.

${ }^{14}$ CRELlin, J. K. - "Early Poison, Medicine and Dispensing Regulations at St George’s Hospital, London”. Pharmaceutical Journal. 190 (1963) p. 197.

15 ANNING, S. T. - “The Apothecaries of the General Infirmary at Leeds”. Medical History. 5 (1961) p. 221.

16 WEBSTER, C. - The National Health Service since the War. London: HMSO, 1988. Volume 1: Problems of Health Care; The National Health Service Before 1957.

17 RIVETT, G. C. - From Cradle to Grave: Fifty years of the NHS. London: King's Fund, 1998.

18 MATTHEWS, L.G. - History of Pharmacy in Britain. London and Edinburgh: Livingstone, 1962.

19 HOLlOWAY, S. W. F. - The Royal Pharmaceutical Society of Great Britain 1841-1991: A Political and Social History. London: The Pharmaceutical Press, 1991.

20 FISH, J. W. B. - The Guild of Hospital Pharmacists 1923 to 1983: Some of the Milestones. London: Guild of Hospital Pharmacists, 1983.

${ }^{21}$ BROOKES, W. T. - History of the Guild 1983 to 1997. London: Guild of Hospital Pharmacists, 1998.

22 WHITTET, T. D. - Idem. p. 17-44.

${ }^{23}$ GRANSHAW, L.; PORTER, R. (eds.) - The Hospital in History. London: Routledge, 1989.

24 POYNTER, F. N. L. (ed.) - The Evolution of Hospitals in Britain. London: Pitman Medical Publishing, 1964.

25 MATTHEWS, L. G. - History of Pharmacy in Britain. London and Edinburgh: Livingstone, 1962. p. 175.

${ }^{26}$ HOLLOWAY, S. W. F. - The Royal Pharmaceutical Society of Great Britain 1841-1991: A Political and Social History. London: The Pharmaceutical Press, 1991. p. 265. 
${ }^{27}$ ELWOOD, W. J.; TUXFORD, F. A. (eds.) - Some Manchester Doctors: A Biographical Collection to mark the 150th Anniversary of the Manchester Medical Society 1834 to 1984. Manchester: Manchester University Press, 1984. p. 127-8.

${ }^{28}$ ANDERSON, S. C. - “'An Intemperate Uncertificated Medico': The Hospital Pharmacist in Great Britain Before 1923”. Pharmaceutical Historian. 31: 1 (2001) p. 12-16.

${ }^{29}$ FISH, J. W. B. - The Guild of Hospital Pharmacists 1923 to 1983: Some of the Milestones. London: Guild of Hospital Pharmacists, 1983. p. 2.

${ }^{30}$ HUNTING, P. - A History of the Society of Apothecaries. London: Society of Apothecaries. 1998. p. 230.

31 PHillipsON, W. E. In Brookes, W.T. - A Mark of Excellence: A History of the Evans Medal. Leatherhead: Evans Medical, 1994. p. 34.

32 LLOYD, J. B. In BROOKES, W.T. - Idem, p. 16.

33 NEWMAN, F.H. In BROOKES, W.T. - Idem, p. 16.

${ }^{34}$ Report of the Committee of Inquiry. London: Pharmaceutical Society of Great Britain, 1941. Part 2, p. 8.

35 SUMMERFIELD, L. - Interviewed 16.10.98. London: National Sound Archive (NSA). Accession No.C917/32. Tape 2A.

${ }^{36}$ MYERS, J. - Interviewed 29.08.97. NSA. Accession No.C917/07. Tape 2B.

37 BEARMAN, J. - Interviewed 17.05.95. NSA. Accession No.C816/02. Tape 1B.

38 HOLLOWAY, S.W.F. - Idem, p. 349.

39 TALLETT, E. - Interviewed 07.08.97. NSA Accession No.C917/04. Tape 2A.

40 MANDER, G. - Interviewed 03.11.98. NSA. Accession No.C917/36. Tape 3A.

41 SHAW, A. - Interviewed 28.11.97. NSA Accession No.C917/09. Tape 1B.

42 MANDER, G. - Idem. Tape 2B.

${ }^{43}$ HIRST, E. - Interviewed 24.08.98. NSA Accession No.C917/23. Tape 3A.

44 TRASLER, B. - Interviewed 08.08.95. NSA Accession No.C816/03. Tape 2B.

45 ANDERSON, S. C. - "Community Pharmacy and the Rise of Welfare in Great Britain 1900 to 1986”. Supplement to Pharmaceutical Historian. 36, 2 (2006) S10-S17.

46 GISBORNE, K. - Idem. Tape 2A.

47 MANDER, G. - Idem. Tape 1B.

- HOLLOWAY S.W.F. - Idem. p.350.

48 BROOKES, W.T. - Interviewed 25.08.98. NSA Accession No.C917/24. Tape 3A.

49 HOLLOWAY S.W.F. - Idem. p.346.

50 Anon (1955) "Report of the Sub-Committee on the Hospital Pharmaceutical Service". London: HMSO (First Linstead Report). p.3.

51 First Linstead Report. Idem, p.17.

52 First Linstead Report. Idem, p.32.

53 Anon (1958) "Report of the Sub-Committee on the Hospital Pharmaceutical Service". London: HMSO (Second Linstead Report).

54 BARRETT, C. - Interviewed 14.08.98. NSA. Accession No.C917/22. Tape 2B.

55 BARRETT, C. - Idem. Tape 2B.

56 DOLLERY, C. - "Medicine and the Pharmacological Revolution". Journal of the Royal College of Physicians of London. 28: 1 (1994) p.59-69.

57 GREENLEAF, J. - Interviewed 30.01.98. NSA Accession No.C917/16. Tape 3A. 
58 ANDERSON. S.C. - "Evidence, Experts and Committees: The Shaping of Hospital Pharmacy Policy in Great Britain 1948 to 1974". In BERRIDGE, V.S. (Ed.) - Making Health Policy: Networks in Research and Policy after 1945. Amsterdam: Rodopi, 2005. Chapter 7.

59 DHSS Report on the Control of Dangerous Drugs and Poisons in Hospitals (Aitken Report). London: HMSO, 1958. p.18.

${ }^{60}$ Pharmacy: A Report to the Nuffield Foundation. London: Nuffield Foundation (Nuffield Report), 1986.

${ }^{61}$ Investigation into the Provision of Pharmaceuticals to Health Authorities. London: MMM Consulting, 1986.

62 CROOK, J.; CALDER, G. - "Hospital pharmacists on the ward". Pharmaceutical Journal. 196 (1966) p. 242-244.

63 ASHCROFT, C. - Interviewed 26.08.98. NSA Accession No.C917/25. Tape 3A.

${ }^{64}$ ANDERSON. S.C. - "Evidence, Experts and Committees". Idem. p.204.

65 Pharmacy: A Report to the Nuffield Foundation. London: Nuffield Foundation (Nuffield Report), 1986. 133 p.

${ }^{66} \mathrm{HC}(88) 54$, (1988), "Health Services Management: The Way Forward for Hospital Pharmaceutical Services", Health Circular, Department of Health.

${ }^{67}$ ELLIS, S. - "The development of pharmacy in hospital”. In ANDERSON, S.C. (ed.) - Making Medicines: A brief history of pharmacy and pharmaceuticals. London: Pharmaceutical Press, 2005. p. 148.

${ }^{68}$ GORSKY, M.; SHEARD, S. - Financing Medicine: The British Experience since 1750. London: Routledge, 2006. p. 247.

${ }^{69}$ HETHERINGTON, C. - Interviewed 27.08.98. NSA. Accession No.C917/26. Tape 3A.

70 DEPARTMENT OF HEALTH - Working for Patients. London: HMSO, 1989.

71 Skill Mix in the Hospital Pharmacy Service. Brighton; Sussex: Institute of Manpower Studies, 1992.

72 ANDERSON, S.C. - Idem. 2005. 212. 